
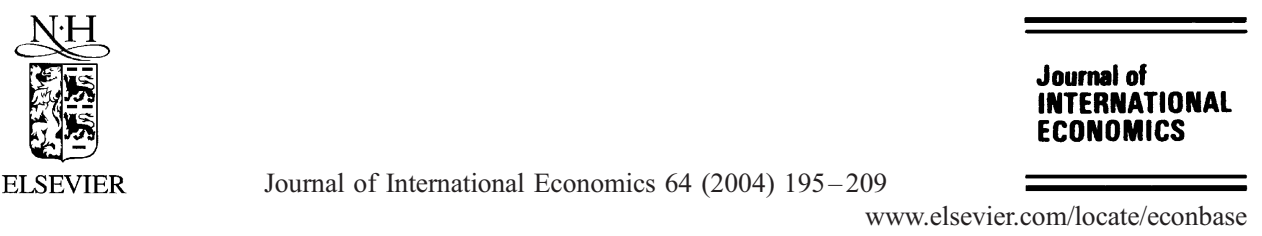

\title{
Rivalry in uncertain export markets: commitment versus flexibility
}

\author{
Gerda Dewit $^{\mathrm{a}, *}$, Dermot Leahy ${ }^{\mathrm{b}, 1}$ \\ ${ }^{a}$ National University of Ireland Maynooth, Department of Economics and Finance, Maynooth, Co. \\ Kildare, Ireland \\ ${ }^{\mathrm{b}}$ University College Dublin, Department of Economics, Belfield, Dublin 4, Ireland
}

Received 3 April 2001; received in revised form 10 July 2002; accepted 10 February 2003

\begin{abstract}
This paper examines optimal trade policy in a two-period oligopoly model, with a home and a foreign firm choosing capital and output. Demand uncertainty, resolved in period two, gives rise to a trade-off between strategic commitment and flexibility in the firms' investment decisions. Firms' investment timing is endogenous and can be manipulated by the home government, which sets a subsidy before firms decide when to invest. We show that when the government wishes to manipulate investment timing, it will choose its policy to deter investment commitment by the home or the foreign firm.
\end{abstract}

(C) 2003 Elsevier B.V. All rights reserved.

Keywords: Demand uncertainty; Strategic commitment; Flexibility; Trade policy; Commitment deterrence

JEL classification: D80; F12; F13

\section{Introduction}

The vast majority of investment decisions share three characteristics. Firstly, they are carried out under uncertainty about future economic conditions. Secondly, the investment, once it has taken place, is at least partly irreversible. Thirdly, the actual timing of the investment is crucial. These three features of investment shape policy both in a micro- and a macroeconomic setting.

\footnotetext{
* Corresponding author. Tel.: +353-1-708-3776; fax: +353-1-708-3934.

E-mail addresses: gerda.dewit@may.ie (G. Dewit), dermot.m.leahy@ucd.ie (D. Leahy).

${ }^{1}$ Tel.: +353-1-716-8551; fax: +353-1-283-0068.
} 
The industrial organisation literature (surveyed by Tirole, 1988, and Shapiro, 1989) stresses the strategic importance of investment irreversibility. Firms commit early to capital, capacity or R\&D with the aim of influencing the future course of the game. In these models, it is typically assumed that firms do not face uncertainty about future demand when choosing their investment level. However, with uncertainty, it is clear that strategically motivated investment commitment by rival firms implies the loss of flexibility required for adjusting to unexpected demand changes. Dixit and Pindyck (1994) have stressed the importance of investment flexibility for a wide range of economic applications. In contrast to the literature on strategic commitment, their option approach to investment emphasises the value of delaying investment until (at least part of) the uncertainty has been resolved.

It is easy to make the case that strategic commitment and flexibility play a key role in real-world investment decisions. Different trading blocs often fight for leadership in key industries, especially in newly emerging markets such as Southeast Asian economies and the reformed economies of Central and Eastern Europe. While early investment, fuelling an aggressive exporting approach to these markets, may allow the leading exporter to capture high rents, it also carries the risk of being overambitious. This is particularly true for many developing regions where the macroeconomic climate is unstable. To address this issue, this paper examines the trade-off between investment flexibility and strategic commitment from the points of view of both firms and policy makers.

From the perspective of firms, a choice needs to be made between investing early and retaining the flexibility to cope with demand fluctuations. Retention of flexibility may, however, imply the surrender of a first-mover advantage ${ }^{2}$. Spencer and Brander (1992) consider the trade-off between commitment and delay from the point of view of firms but their model does not address government policy.

From the perspective of policy-makers, firms may invest too early or too late. More specifically, in our model a government that can affect investment timing chooses its optimal policy in a strategic setting with uncertainty. In particular, governments with commitment power may wish to encourage or discourage investment commitment by firms. The question we address is quite different from the one raised in Arvan (1991). He studies the commitment-flexibility trade-off from the point of view of governments that choose when-before or after the resolution of uncertainty-to set their subsidy. Moreover, in his set-up, unlike in our model, firms do not invest.

We use a dynamic oligopoly model in which a home and a foreign firm invest in capital and export to a third market, and the home government chooses its trade policy ${ }^{3}$. We

\footnotetext{
2 The question of when to invest naturally gives rise to endogenous timing in the investment game. Since the 1980 s there has been considerable interest in the issue of endogenous timing in the choice of strategic variables in oligopolistic markets. See, for instance, Gal-Or (1985), Dowrick (1986), Boyer and Moreaux (1987), Hamilton and Slutsky (1990).

3 The key early papers on trade policy towards exporting oligopolists without capital investment include Brander and Spencer (1985) and Eaton and Grossman (1986). Spencer and Brander (1983) examine a model similar to these that includes an investment stage. Brander (1995) provides a comprehensive survey of this literature.
} 
examine the case in which the home government is able to use an export subsidy to influence the game played by firms ${ }^{4,5}$. We explore how a government with commitment power affects the firms' strategic investment decisions for an export market where demand uncertainty prevails. In our model there are two periods, during the first of which players face uncertainty about future demand in the export market. In period two, when actual outputs are chosen, uncertainty disappears ${ }^{6}$.

We show that governments can, and may wish to, alter the relative advantages of investment flexibility to the home firm and its foreign rival. This involves intervention to strategically manipulate the timing of home or foreign investment. The government can force the foreign firm to remain flexible or persuade the home firm to avoid commitment. This policy will be referred to as "Commitment deterrence". The possibility of "Commitment inducement"-manipulating the domestic firm or its rival to enforce early investment-is also explored.

In Section 2 we describe the basic model in which a home and a foreign firm choose the timing and level of their investment and export to a third market characterised by demand uncertainty. In Section 3, we derive the optimal export policy of the home government. Section 4 deals with a number of extensions of the analysis. The final section concludes and suggests future research directions.

\section{The model}

Consider a home and a foreign firm which are competing à la Cournot in a third market, facing demand uncertainty. The stochastic demand component is denoted by $u$, defined over the closed interval $[\underline{u}, \bar{u}]$ and characterised by a zero mean $(E u=0)$ and variance of $\sigma^{2}$. Demand is given by:

$$
p=a-Q+u
$$

where $p$ is the price prevailing in the export market, $Q=x+y$ is total output, and $x$ and $y$ denote output of the home and foreign firm, respectively. Firms also invest in capital,

\footnotetext{
4 Although the WTO Subsidy-Code prohibits the use of export subsidies, most countries surreptitiously use forms of export subsidisation. The public provision of cheap loans to finance export activities (e.g., export credits) is one example through which significant subsidies were channelled indirectly to exporters in the late 1980s and 1990s (Stephens, 1999), especially to firms targeting newly emerging markets.

5 Expanding the number of policy instruments increases the model's complexity without yielding additional insights. The model we discuss here is similar in structure to Grossman and Maggi (1998) in which firms choose capital and output and the government chooses an export subsidy. Goldberg (1995) and Karp and Perloff (1995) adopt a similar approach. In Neary and O'Sullivan (1999) the firms choose R\&D and output while the government chooses an export subsidy. Like these papers we do not discuss the first-best policy, which entails a mix of investment and export subsidies. For a comprehensive discussion of first-best versus second-best cases without uncertainty and endogenous timing, see Neary and Leahy (2000).

6 This temporal structure is similar to that in Cooper and Riezman (1989) and Arvan (1991).
} 
represented by $k$ and $k^{*}$. Henceforth, starred variables refer to the foreign firm. We assume the firms' total cost functions (TC, $\left.\mathrm{TC}^{*}\right)$ are:

$$
\begin{aligned}
& \mathrm{TC}=\left(c_{0}-k\right) x+\frac{k^{2}}{2 \eta} \\
& \mathrm{TC}^{*}=\left(c_{0}^{*}-k^{*}\right) y+\frac{k^{* 2}}{2 \eta}
\end{aligned}
$$

where $c_{0}$ and $c_{0}^{*}$ are constants; $c_{0}-k$ and $c_{0}^{*}-k^{*}$ represent the marginal cost of production for the home and the foreign firm, respectively. The capital cost for each firm is captured by the second terms in Eqs. (2a) and (2b); $\eta$ is a constant, which is assumed to be identical for both firms ${ }^{7}$.

There are two periods, during the first of which players face uncertainty about future demand in the export market. At the start of period two, in which the actual output is chosen, uncertainty disappears. Firms have the option to commit strategically to investment in period one. However, since this choice implies foregoing capital flexibility in the second period, commitment is less appealing at high levels of uncertainty. If investment is delayed until period two, capital is chosen simultaneously with output and optimally for the demand then prevailing.

The model we use is a two-period four-stage game, which is depicted in Fig. 1. In stage one, the home government sets an export subsidy. In stage two, firms decide whether to invest in period one or two and are then committed to this decision. Home firm commitment is represented by $C$, while $D$ stands for delay; $C^{*}$ and $D^{*}$ represent commitment and delay for the foreign firm. In stage three, firms that are committed to invest in period one choose their actual capital level. This investment decision is irreversible. In stage four, firms choose outputs simultaneously and firms that have not yet chosen their capital do so ${ }^{8}$.

For simplicity, players are assumed to be risk neutral ${ }^{9}$. Profits for the home and foreign firm are given by:

$$
\begin{aligned}
& \pi=(p+s) x-\mathrm{TC} \\
& \pi^{*}=p y-\mathrm{TC}^{*}
\end{aligned}
$$

7 Grossman and Maggi (1998) use the same cost specification. It is also commonly used in the process R\&D literature (see d'Aspremont and Jacquemin, 1988).

8 In the terminology of Hamilton and Slutsky (1990), the game we examine here is one with "Observable delay". In a model without policy, Dewit and Leahy (2001) also consider an alternative game structure in which the firms cannot simply commit to a timing of investment. Instead, a firm can only choose its capital early by selecting the level of first-period capital investment to which it is then committed. Hamilton and Slutsky refer to this type of extended game as one with "Action commitment". They examine and compare extended games of observable delay and action commitment in simple output and price games without prior capital investment or uncertainty.

9 Risk aversion raises the range of uncertainty over which flexibility is preferred to commitment and complicates the analysis significantly, but without changing the qualitative nature of our results. 


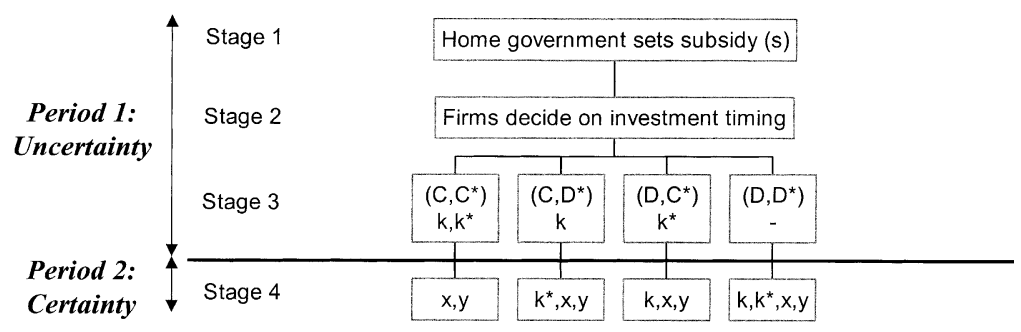

Fig. 1. The sequence of moves in the game.

with $s$ denoting the home government's export subsidy. Using backward induction, we start by solving the final stage of the game. When choosing outputs in the last stage, firms maximise second-period profits. Optimal outputs for the home and the foreign firm are, respectively given by:

$$
\begin{aligned}
& x=\left(2 A-A^{*}+2 s+2 k-k^{*}+u\right) / 3 \\
& y=\left(2 A^{*}-A-s+2 k^{*}-k+u\right) / 3
\end{aligned}
$$

We define $A \equiv a-c_{0}, A^{*} \equiv a-c_{0}^{*}$. Initially, we assume firms' costs are the same $\left(A=A^{*}\right)$. The implications of relaxing this assumption are discussed in Section 4.

Table 1 reports the optimal capital levels for the different investment timing combinations. The first superscript on the variables refers to commitment (c) or delay (d) by the home firm, while the second superscript denotes commitment $(\mathrm{c} *)$ or delay $(\mathrm{d} *)$ by the foreign firm. A firm can increase its output flexibility by delaying its investment until uncertainty is resolved. Firms that delayed investment choose investment levels in the last stage, maximising second-period profits with respect to capital. This implies that capital is a function of the actual demand realisation, $u$ [see $k^{\mathrm{dd}^{*}}(u), k^{* \mathrm{dd}^{*}}(u), k^{\mathrm{dc}}(u)$ and $k^{* \mathrm{~cd}^{*}}(u)$ in Table 1]. Firms that opted for capital commitment have fixed their investment levels earlier. More specifically, they determine optimal investment levels in stage three by maximising expected profits with respect to capital. With commitment, capital no longer depends on $u$ [see $k^{\mathrm{cc}^{*}}, k^{* \mathrm{cc}^{*}}, k^{\mathrm{cd}}$ and $k^{* \mathrm{dc}}$ in Table 1]. Looking again at expressions (4a) and (4b) together with the expressions in Table 1, we see that flexibility in a firm's own investment reinforces the effect of $u$ on its output. Hence, a firm's investment flexibility enhances its output flexibility.

However, because investment flexibility implies that capital is chosen simultaneously with output, it precludes strategic investment. Instead, investment is chosen to minimise $\operatorname{cost}(k=\eta x)$. When both firms commit, each firm strategically over-invests compared to

Table 1

\begin{tabular}{|c|c|c|c|c|}
\hline & $C, C^{*}$ & $C, D^{*}$ & $D, C^{*}$ & $D, D^{*}$ \\
\hline$k$ & $k^{\mathrm{cc}^{*}}=\frac{4}{3} \eta E x^{\mathrm{cc}^{*}}$ & $k^{\mathrm{cd} *}=\frac{2(2-\eta)}{3-2 \eta} \eta E x^{\mathrm{cd}^{*}}$ & $k^{\mathrm{dc}^{*}}(u)=\eta x^{\mathrm{dc} *}(u)$ & $k^{\mathrm{dd}^{*}}(u)=\eta x^{\mathrm{dd}^{*}}(u)$ \\
\hline$k^{*}$ & $k^{* \mathrm{cc}^{*}}=\frac{4}{3} \eta E y^{\mathrm{cc} *}$ & $k^{* \mathrm{~cd}^{*}}(u)=\eta y^{\mathrm{cd} *}(u)$ & $k^{* \mathrm{dc}^{*}}=\frac{2(2-\eta)}{3-2 \eta} \eta E y^{\mathrm{dc} *}$ & $k^{* \mathrm{dd}^{*}}(u)=\eta y^{\mathrm{dd}^{*}}(u)$ \\
\hline
\end{tabular}

Optimal capital levels for the different investment timing combinations 
Table 2

Maximised expected profits for the different investment timing combinations

\begin{tabular}{lllll}
\hline & $C, C^{*}$ & $C, D^{*}$ & $D, C^{*}$ & $D, D^{*}$ \\
\hline$E \pi$ & $\gamma\left(E x^{\mathrm{cc}}\right)^{2}+\frac{1}{9} \sigma^{2}$ & $\zeta\left(E x^{\mathrm{cd}}\right)^{2}+\left(\frac{1-\eta}{3-2 \eta}\right)^{2} \sigma^{2}$ & $\varphi\left(E x^{\mathrm{dc}}\right)^{2}+\frac{1-\eta / 2}{(3-2 \eta)^{2}} \sigma^{2}$ & $\varphi\left(E x^{\mathrm{dd}^{*}}\right)^{2}+\frac{1-\eta / 2}{(3-\eta)^{2}} \sigma^{2}$ \\
$E \pi^{*}$ & $\gamma\left(E y^{\mathrm{cc}}\right)^{2}+\frac{1}{9} \sigma^{2}$ & $\varphi\left(E y^{\mathrm{cd}}\right)^{2}+\frac{1-\eta / 2}{(3-2 \eta)^{2}} \sigma^{2}$ & $\zeta\left(E y^{\mathrm{dc}}\right)^{2}+\left(\frac{1-\eta}{3-2 \eta}\right)^{2} \sigma^{2}$ & $\varphi\left(E y^{\mathrm{dd}}\right)^{2}+\frac{1-\eta / 2}{(3-\eta)^{2}} \sigma^{2}$ \\
\hline
\end{tabular}

With $\gamma \equiv 1-(8 / 9) \eta, \zeta \equiv 1-2 \eta[(2-\eta) /(3-2 \eta)]^{2}$ and $\varphi \equiv 1-\eta / 2$.

the cost-minimising level, attempting to reduce the rival's future output. When only one firm commits, that firm's incentive to strategically over-invest increases: the higher investment level now reduces the rival's future output and future capital level. Thus, a firm that commits while its rival delays will choose its investment in the most strategically aggressive manner and will gain the highest possible strategic advantage. From Table 1, we have the following capital-output ranking: $k^{\mathrm{cd}^{*}} / E x^{\mathrm{cd}^{*}}>k^{\mathrm{cc} *} / E x^{\mathrm{cc}^{*}}>k^{\mathrm{dc}^{*}} / x^{\mathrm{dc} *}=$ $k^{\mathrm{dd}^{*}} / x^{\mathrm{dd} *}$.

In stage two, firms decide whether to invest early or later, choosing the timing that yields the highest expected profits. Since expected profits increase in output flexibility, firms will only commit to capital if this choice generates strategic gains that are sufficiently large to compensate for the losses suffered by foregoing flexibility ${ }^{10}$. Table 2 gives maximised expected profits for the different investment timing combinations.

The export subsidy, set by the home government in stage one, has the usual effects of an expansion in home output and a reduction in foreign output. In addition, it can also affect firms' investment timing. The subsidy increases the relative attractiveness of commitment to the home firm, and lowers it to the foreign firm. Capital commitment raises a firm's output. Since the subsidy widens the home firm's price-cost gap, it raises the return to the output expansion that results from capital commitment. Conversely, for the foreign firm, the subsidy narrows the price-cost gap (as home output increases, the price falls), therefore reducing the return to investment commitment. We will show that these subsidy-induced effects on investment timing are important in determining the government's optimal subsidy policy.

\section{Optimal trade policy and "commitment deterrence"}

In stage one, the government sets the subsidy to maximise expected welfare, $E W$, given by:

$$
E W=E \pi-s E x
$$

10 Because $x$ and $y$ depend linearly on $u$ (see expressions (4a) and (4b)), profits are convex in $u$, implying that expected profits increase in the variance of $u$. Due to the indirect effect of capital on output, the effect of the variance on expected profits is larger under investment flexibility than with commitment. This generates the tradeoff between flexibility and commitment in our model. Our model thus captures the stylised fact that, ceteris paribus, investors prefer projects that allow flexibility to those that require investing in capital that is irrevocably fixed. Arvan (1991) and Spencer and Brander (1992) use a similar approach. 
The subsidy is a profit-shifting strategic trade policy instrument ${ }^{11}$, but — as pointed out in Section 2-it can also affect firms' investment timing. For each possible investment timing combination, there is an optimal rent-shifting subsidy. (These are reported in Table A.1 of Appendix A). However, because the subsidy alters the relative advantage of investment flexibility for firms, the government can and may wish to induce a change in firms' investment timing. To do so requires deviating from the optimal rent-shifting policy. It will choose to do so if the policy of timing manipulation (which is suboptimal in terms of rent-shifting) yields a higher expected welfare level than a policy of optimal rentshifting (which leaves firms' investment timing unaltered).

Timing manipulation complicates the analysis considerably. So, before turning to the game in which both firms' investment timing is endogenous, it proves useful to explore the policy maker's problem by studying four simplified cases, henceforth referred to as cases I to IV. In each case, only one firm chooses either to invest early or to delay while the investment timing of its rival is exogenous. More specifically, we discuss the home government's optimal policy (i) when only the home firm chooses its investment timing assuming that the foreign firm delays its investment (case I) and (ii) assuming, alternatively, that the foreign firm invests early (case II). Subsequently, the optimal export subsidy is derived (iii) when only the foreign firm chooses when to invest, assuming that the home firm delays (case III) and (iv) assuming, alternatively, that the home firm commits (case IV). The insights that emerge from these cases are helpful in understanding the government's optimal export subsidy in the game in which both firms' investment timing choices are endogenous.

Since the analysis involves many unwieldy algebraic expressions, diagrams are extensively used to ease the exposition. This approach allows us to minimise the number of equations we give in the text, but does not reduce the generality of our analysis in any way. In the figures, $A$ is normalised at unity without loss of generality.

\subsection{Only one firm chooses investment timing: four cases}

\subsubsection{Case I: Home firm chooses timing given exogenous foreign delay}

This case is shown in Fig. 2, which depicts the relationship between the level of uncertainty $\left(\sigma^{2}\right)$ and the export subsidy $(s)$ for a given level of $\eta^{12}$. Here, given exogenous foreign delay, $\left(C, D^{*}\right)$ and $\left(D, D^{*}\right)$ are the two possible investment timing combinations. The policy active home government wants its own firm to delay its investment: delay allows home investment to adjust to unexpected demand shocks and, in addition, avoids the social costs associated with strategic over-investment. In fact, from a welfare perspective, the home government's ability to exploit its first-mover advantage eliminates the need for the home firm to move first, though the firm may still desire to do so. The same reasoning implies that it is never optimal to induce the home firm to commit when it would have chosen to delay.

When uncertainty is high $\left(\sigma^{2} \geq \sigma_{h}^{2}\right)$, the home firm's valuation of flexibility relative to commitment is high. The government sets the subsidy $s^{\mathrm{dd}}{ }^{*}$, which is the optimal rent-

\footnotetext{
11 See Brander (1995).

12 Varying the levels of $\eta$ does not change the qualitative relationship between uncertainty and the export subsidy (see Section 3.2).
} 


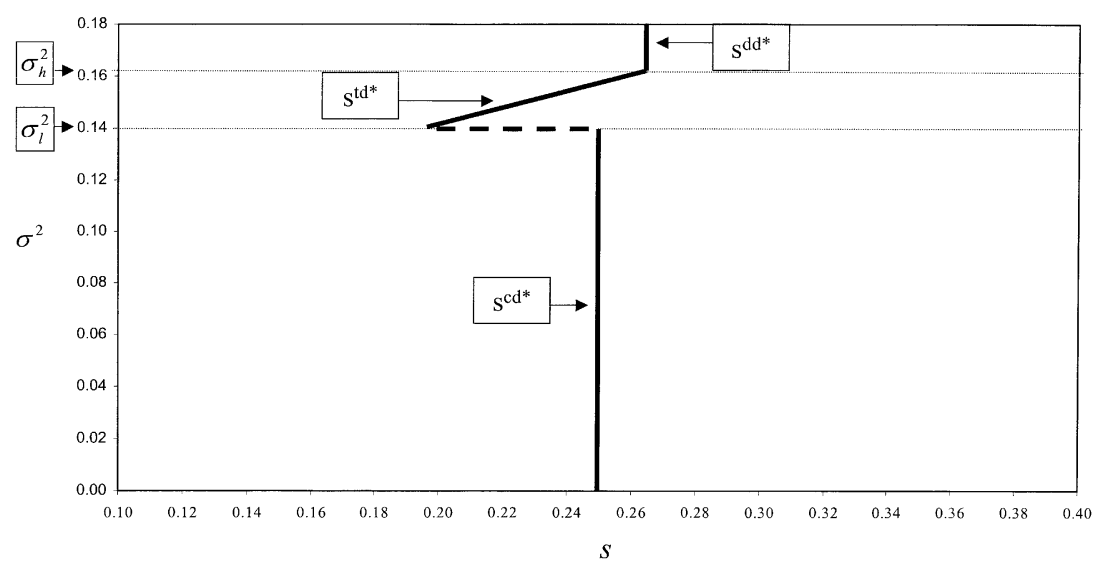

Fig. 2. Optimal subsidisation given foreign firm delay $(A=A *=1 ; \eta=0.03)$.

shifting subsidy for $\left(D, D^{*}\right)$. Below a critical level of uncertainty, $\sigma_{h}^{2}$, the firm would choose to commit at $s^{\mathrm{dd}^{*}}$. The government can only prevent this by setting a lower subsidy, thus reducing the firm's incentive to commit. We refer to this strategy as "Commitment deterrence". The subsidy $s^{\text {td }}$ is the highest subsidy consistent with home delay, given foreign delay. It increases in the level of uncertainty. As uncertainty falls, the firm values flexibility less and therefore a lower subsidy is required to force the firm to delay. While commitment deterrence forces the home firm to delay-which raises welfare - it also implies deviating from the optimal rent-shifting subsidy for $\left(D, D^{*}\right)$, and thus involves a welfare cost. This cost is larger as uncertainty falls, since then the deviation of $s^{\text {td }}$ from $s^{\mathrm{dd}^{*}}$ becomes greater. However, provided that uncertainty is sufficiently high, the difference between $s^{\mathrm{td} *}$ and $s^{\mathrm{dd}^{*}}$ remains relatively small, and the lost rent-shifting associated with commitment deterrence is dominated by flexibility benefits. So, at intermediate levels of uncertainty $\left(\sigma_{l}^{2}<\sigma^{2}<\sigma_{h}^{2}\right)$, the government deters commitment by its home firm by setting the subsidy $s^{\text {td }}$.

At low levels of uncertainty $\left(\sigma^{2} \leq \sigma_{l}^{2}\right)$, commitment deterrence requires too large of a departure from the optimal rent-shifting subsidy. A less costly policy then entails accepting home firm commitment and choosing $s^{\mathrm{cd} *}$, which is the optimal rent-shifting subsidy for $\left(C, D^{*}\right)$. We refer to this latter policy as one of "timing accommodation". Formally, $E W\left(s^{\text {cd }^{*}} ; C, D^{*}\right) \geq E W\left(s^{\text {td }} ; D, D^{*}\right)$ at $\sigma^{2} \leq \sigma_{l}^{2}$.

\subsubsection{Case II: Home firm chooses timing given exogenous foreign commitment}

Now, the two possible timing combinations are $\left(D, C^{*}\right)$ and $\left(C, C^{*}\right)$. The policy in this case closely resembles that in the previous case. The home government will accommodate home commitment when uncertainty is low, and thus chooses the subsidy $s^{\mathrm{cc}^{*}}$, the optimal rent-shifting subsidy for $\left(C, C^{*}\right)$. The main difference from the previous case is that the foreign firm now invests strategically. Moreover, its strategic behaviour is strongest in $\left(D, C^{*}\right)$, that is, when it invests before the home firm. Thus, commitment by the home firm has the beneficial effect of "softening" the strategic aggressiveness of the foreign firm $\left(k^{* c^{*}} / E y^{\mathrm{cc}^{*}}<k^{* \mathrm{dc} *} / E y^{\mathrm{dc}}\right)$. This does not occur in case I $\left(k^{* \mathrm{dd}^{*}} / E y^{\mathrm{dd}^{*}}=k^{* \mathrm{~cd}^{*}} / E y^{\mathrm{cd}^{*}}\right)$ 


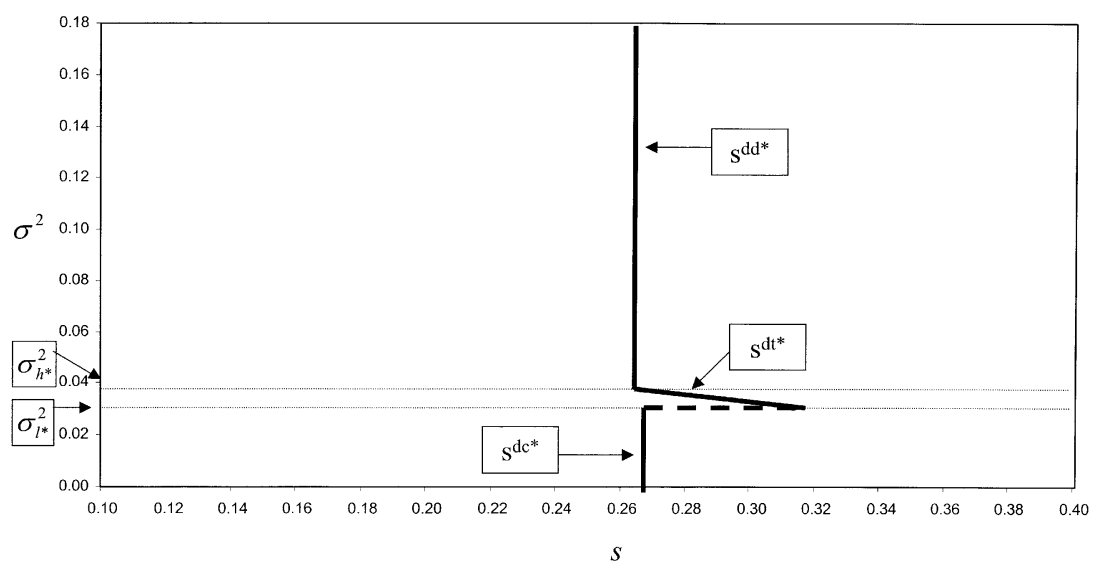

Fig. 3. Optimal subsidisation given home firm delay $(A=A *=1 ; \eta=0.03)$.

as the foreign firm chooses its capital non-strategically when it delays. From a home welfare perspective, home firm commitment now has a beneficial effect that needs to be weighed against the negative welfare effects mentioned earlier. For this reason, the government continues to accommodate home commitment at higher levels of uncertainty than in case $\mathrm{I}^{13}$. However, when uncertainty is sufficiently high, it prefers, for the same reasons as in case I, to deter home commitment with a discrete cut in the subsidy to $s^{\text {tc }}$ (the highest subsidy consistent with home delay, given foreign commitment). As uncertainty increases further, $s^{\mathrm{tc}}{ }^{*}$ rises, eventually reaching $s^{\mathrm{dc} *}$, the optimal rent-shifting subsidy for $\left(D, C^{*}\right)$. At and above that level of uncertainty, the firm willingly delays.

\subsubsection{Case III: Foreign firm chooses timing given exogenous home delay}

The two possible timing combinations are now $\left(D, D^{*}\right)$ and $\left(D, C^{*}\right)$. The home government would like the foreign firm to delay its investment so that it will not behave strategically, setting a high investment level. Fig. 3 depicts the optimal subsidy at different levels of uncertainty. At high uncertainty levels, the foreign firm chooses to delay at the subsidy level $s^{\mathrm{dd} *}$, the optimal rent-shifting subsidy for $\left(D, D^{*}\right)$. Below a threshold level of uncertainty $\left(\sigma_{h^{*}}^{2}\right)$, the home government can maintain foreign firm delay but only by choosing the higher commitment deterrence subsidy given home delay, $s^{\mathrm{dt} *}$. As uncertainty continues to fall and the attraction of commitment for the foreign firm increases, commitment deterrence requires an ever greater departure from the optimal rent-shifting subsidy for $\left(D, D^{*}\right)$ and thus becomes increasingly costly. Eventually, for $\sigma^{2} \leq \sigma_{l^{*}}^{2}$, the government abandons commitment deterrence by choosing $s^{\mathrm{dc} *}$, and $\left(D, C^{*}\right)$ emerges as the equilibrium investment timing ${ }^{14}$.

\footnotetext{
13 This beneficial effect is never sufficient to make the government choose to induce home commitment.

14 Inducing the foreign firm to commit is never an attractive option for the government, in spite of the flexibility advantage to the home firm if it is the only one to delay. This flexibility gain would only outweigh the second-mover disadvantage at very high levels of uncertainty, when flexibility is also very attractive to the foreign firm. Hence, inducing foreign commitment would imply that the home firm would have to be very heavily taxed. This is simply never optimal.
} 


\subsubsection{Case IV: Foreign firm chooses timing given exogenous home commitment}

As shown above, the government would prefer the foreign firm to delay. At high levels of uncertainty, commitment deterrence is unnecessary: the $\left(C, D^{*}\right)$-equilibrium prevails and the government chooses $s^{\mathrm{cd} *}$. At intermediate levels of uncertainty, the government deters foreign commitment by using the subsidy $s^{\text {ct* }}$, the lowest possible subsidy that deters foreign commitment when the home firm commits. At very low levels of uncertainty, the $s^{\mathrm{ct}^{*}}$-subsidy is so high that deterrence is too costly; the government then chooses to accommodate foreign commitment with the subsidy $s^{\mathrm{cc} *}$.

\subsection{Both firms choose investment timing}

Having analysed cases I to IV, we are now ready to consider the game described in Fig. 1 in which both firms' investment timing decisions are endogenous. The outcome of the game at different parameter values is presented in Fig. 4a and b. While Fig. 4a depicts the optimal subsidy at different $\sigma^{2}$-levels keeping $\eta$ constant, Fig. $4 \mathrm{~b}$ represents the outcomes in $\left(\sigma^{2}, \eta\right)$-space. As explained earlier, the government would wish both the home and the foreign firm to delay investment but it would also like to set the subsidy as close as possible to the optimal rent-shifting level for the timing equilibrium that emerges. In area I in Fig. $4 \mathrm{~b}$, the government sets the subsidy $s^{\mathrm{cc}^{*}}$, the optimal rent-shifting subsidy for $\left(C, C^{*}\right)$. The government accommodates the timing as commitment deterrence is very costly in this region. This is because uncertainty is very low and thus the firms' relative valuation of commitment to flexibility is high.

As uncertainty rises firms' relative valuation of commitment falls and commitment deterrence becomes a feasible policy alternative. As we saw in Section 3.1, commitment deterrence requires deviating from optimal rent-shifting subsidies. Fig. $4 \mathrm{a}$ and $\mathrm{b}$ show that, as uncertainty rises, deterrence of foreign commitment occurs before deterrence of home commitment. Intuitively, with subsidisation of the home firm (giving it a net cost advantage), enforcing foreign firm flexibility is the easier option because commitment has a lower value for the latter than it has for the home firm.

Moving from area I to area II in Fig. 4b implies that the government will switch from accommodating commitment, $\left(s^{\mathrm{cc} *} ; C, C^{*}\right)$, to deterring foreign commitment, while allowing the home firm to commit $\left(s^{\mathrm{ct} *} ; C, D^{*}\right)$. More precisely, this regime switch is indicated by the locus on which deterrence and accommodation of foreign commitment yield the same expected welfare: $E W\left(s^{\mathrm{ct}} ; C, D^{*}\right)=E W\left(s^{\mathrm{cc}} ; C, C^{*}\right)$. In Fig. 4a, this switch occurs at point $e$, at which the subsidy jumps discretely to a higher level. As the level of uncertainty rises, the commitment deterrence subsidy $s^{\mathrm{ct} *}$ falls and approaches $S^{\mathrm{cd} *}$ . Eventually, uncertainty is so high that $s^{\text {ct* }}=s^{\text {cd* }}$ (point $f$ in Fig. 4a), which is the optimal rent-shifting subsidy for $\left(C, D^{*}\right)$. This is indicated in Fig. 4 b by the locus $E \pi^{*}\left(s^{\text {cd* }} ; C\right.$, $\left.C^{*}\right)=E \pi^{*}\left(s^{\mathrm{cd} *} ; C, D^{*}\right)$. At intermediate levels of uncertainty (area III in Fig. 4b), deterring the home firm from committing still proves too costly in welfare terms $\left[E W\left(s^{\mathrm{td}} ; D, D^{*}\right)<E W\left(s^{\mathrm{cd}^{*}} ; C, D^{*}\right)\right]$. Home commitment deterrence becomes sufficiently attractive to the government when the maximum subsidy that enforces home firm flexibility given foreign delay, $s^{\mathrm{td}}$, is high enough $\left[E W\left(s^{\mathrm{td}^{*}} ; D, D^{*}\right)>E W\left(s^{\mathrm{cd}^{*}} ; C, D^{*}\right)\right]$. Hence, home commitment deterrence considerations shape the subsidy policy prevailing in area IV in Fig. 4b. In Fig. 4a, the regime shift (at point $g$ ) is characterised by a discrete 

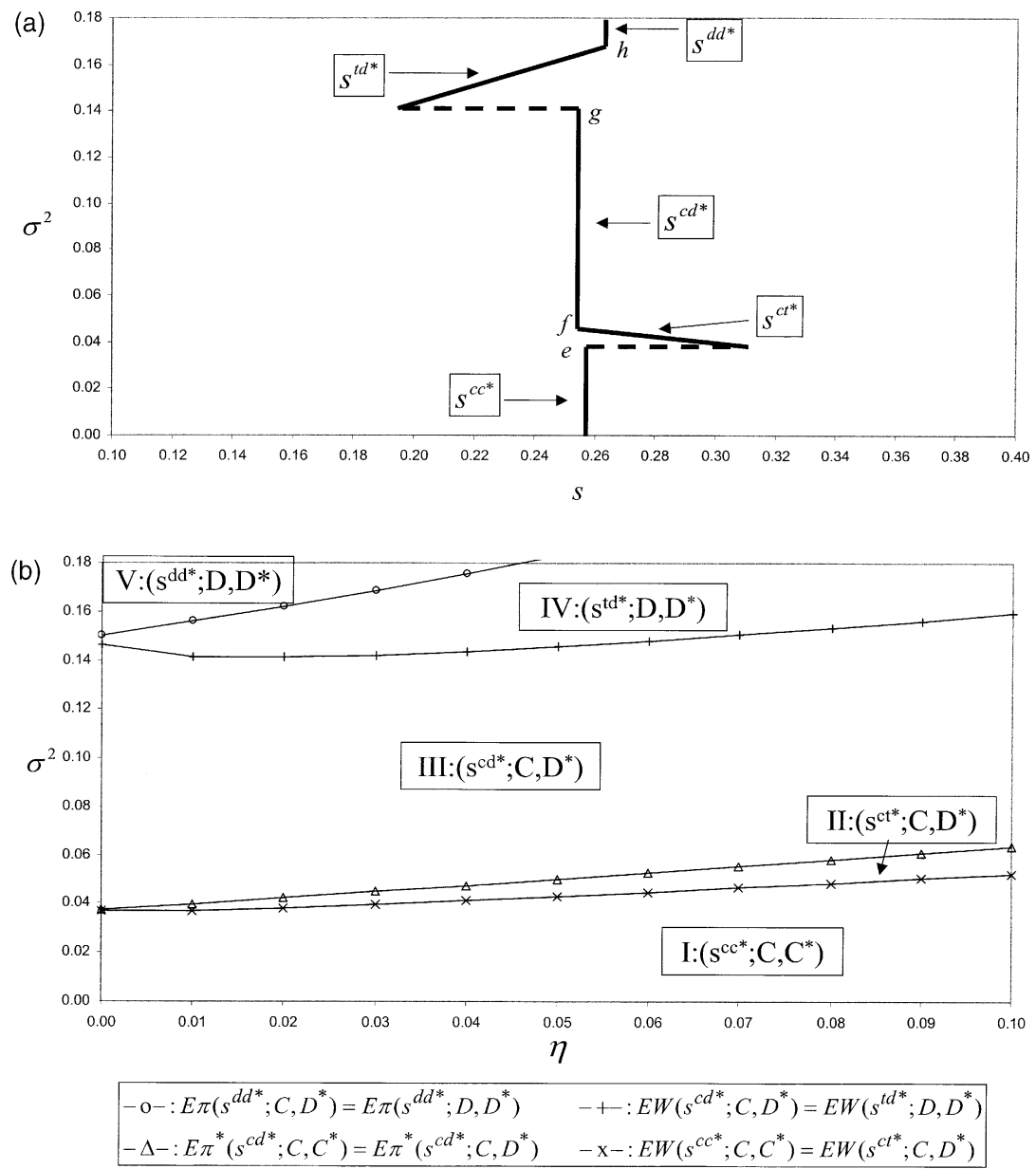

Fig. 4. (a) Optimal subsidisation when both firms choose investment timing in $\left(\sigma^{2}, s\right)\left(A=A^{*}=1 ; \eta=0.03\right)$. (b) Optimal subsidisation when both firms choose investment timing in $\left(\sigma^{2}, \eta\right)$-space $\left(A=A^{*}=1\right)$.

drop in the subsidy level, which is the minimum subsidy deviation necessary to enforce flexibility of the home firm. For higher levels of uncertainty, this policy involves a subsidy closer to the optimal rent-shifting subsidy when both firms remain flexible, $s^{\text {dd }}{ }^{*}$. Eventually, the commitment deterrence subsidy $s^{\text {td }}{ }^{*}$ coincides with $s^{\mathrm{dd}^{*}}$ (point $h$ in Fig. 4 a). At and above the level of uncertainty at which $s^{\mathrm{td}^{*}}=s^{\mathrm{dd}^{*}}$, the government sets $s^{\mathrm{dd}^{*}}$ and both firms delay (area V in Fig. 4b).

\section{Extensions}

This section deals with a number of extensions of the model. We describe how cost asymmetries between firms and the addition of more firms affect our results. We then 
consider how the government's optimal trade policy would change if firms compete in a Bertrand rather than in a Cournot fashion. Finally, we briefly discuss a set-up in which the government cannot commit long-term and must set its trade policy in period two after uncertainty has been resolved.

\subsection{Cost asymmetry}

So far, we considered firms with symmetric costs in the sense that $c_{0}=c_{0} *$. With cost asymmetry ${ }^{15}$, the results do not change qualitatively when the home firm has a cost advantage $\left(c_{0}<c_{0} *\right)$. When the foreign firm has a cost advantage $\left(c_{0}>c_{0} *\right)$, the results only change subtly when this cost advantage is sufficiently large to outweigh the subsidy advantage of the home firm. Then, the relationship between the subsidy and the level of uncertainty is similar to the one depicted in Fig. 4a, except that, as uncertainty rises, deterring home commitment now occurs before deterring foreign commitment. This is because, when the foreign firm has a larger price-cost gap, it values commitment more than the home firm. Hence, unlike in the symmetric case, enforcing home rather than foreign firm flexibility is now the easier option.

\subsection{Multiple firms}

With multiple home firms, the optimal subsidy level will be lower due to terms-of-trade considerations ${ }^{16}$. However, the policy towards firms' investment timing is not qualitatively different. Like under Cournot duopoly, if the government wishes to manipulate firms' investment timing, it will deter (i.e., never induce) commitment: it needs to reduce the subsidy below its optimal rent-shifting level to deter its own firms, whereas a subsidy increase is required for foreign commitment deterrence ${ }^{17}$.

\subsection{Bertrand competition}

Consider a modified version of the game described in Fig. 1, in which the home and foreign firm choose prices rather than quantities in stage four, and sell differentiated products ${ }^{18}$. In all other respects, the model remains unchanged. Under Bertrand competition, the optimal export policy involves a tax instead of a subsidy ${ }^{19}$. From a welfare perspective, the government's ability to move first overrides the need for the home firm to commit. Hence, when manipulation of the home firm's timing is optimal, it will involve commitment deterrence. It entails setting the tax above the tax

\footnotetext{
15 For a detailed analysis of the effects of cost asymmetry in a strategic trade model, we refer to earlier work (see, for instance, de Meza, 1986, and Neary, 1994).

16 Conversely, with more foreign firms, the subsidy tends to be higher (see Dixit, 1984).

17 With symmetric firms, multiple equilibria are likely. However, except for the occurrence of narrow bands with multiple equilibria at some ranges of uncertainty, this would not yield a timing equilibria picture that is qualitatively different from the one in Fig. $4 \mathrm{~b}$.

18 This standard assumption of product differentiation avoids the usual problem of the Bertrand paradox.

19 See Eaton and Grossman (1986). Bagwell and Staiger (1994) consider a model with investment and price competition in which the government chooses an investment subsidy.
} 
level chosen when firms' investment timing is not manipulated. For certain levels of uncertainty, the government may consider manipulating the foreign firm's investment timing, but, instead of deterring foreign commitment the government will now choose to induce it by raising the export tax. Unlike in Cournot competition, the strategic behaviour of the foreign firm benefits the home country because it involves strategic under-investment to commit to a high price.

\subsection{Policy flexibility}

In the game we discussed, the government moves first, which presumes that it can credibly commit to its policies long-term. This assumption about the commitment power of the government could be contested, particularly in the context of developing countries. Rodrik (1992) has distinguished between strong and weak states on the basis of their commitment power. Suppose that the government cannot commit to its trade policy long-term, that is, before the firms choose their timing. Instead, assume that the subsidy is set in period two after uncertainty is resolved but before firms' period-two actions are chosen ${ }^{20}$. Since the subsidy in that set-up is chosen in line with actual demand $[s=s(u)]$, it allows the government to exploit unexpected demand shocks in favour of its own firm. However, it also has an important drawback: firms can now influence the subsidy by investing strategically in period one. This encourages firms to invest early. Early investment by the foreign firm in particular has harmful welfare implications due to enhanced strategic aggressiveness in its choice of investment. Furthermore, investment-timing manipulation is ruled out under this type of policy regime. However, policy flexibility entails welfare gains when uncertainty is high and firms choose to delay investment.

\section{Conclusion}

In this paper we have examined optimal trade policy when the timing of firms' investment decisions is endogenous and demand is uncertain. In our set-up, firms face a trade-off between remaining flexible in order to adjust their capital appropriately in the face of uncertain demand, or moving earlier in order to strategically manipulate their rival.

We have shown that endogenous timing of investment creates a new motive for government intervention. The government, setting its subsidy at the beginning of the game before firms decide when and how much to invest, may adjust its policy to affect the investment timing decision of firms. In particular, it may choose to increase or decrease the subsidy to deter private-sector capital commitment. If it chooses to deter foreign commitment this necessitates increasing the export subsidy to reduce the relative advantage of commitment to the foreign firm. By contrast, to deter home commitment and thus guarantee flexible investment by the home firm, while preventing socially non-

\footnotetext{
${ }^{20}$ Of course, if the government has no commitment power at all and hence chooses the subsidy at the same time firms determine outputs, strategic trade policy is impossible.
} 
optimal investment, the government needs to lower the subsidy relative to the subsidy that would be employed if the government was only concerned with rent-shifting.

Before concluding we wish to point out some possible avenues for future research. In this paper we have focussed on demand uncertainty. Firms may also be uncertain about their own and rival's future costs. In that case it would be natural to assume that they know less about their rival's costs than their own. This would raise the issue of asymmetric information that we have assumed away here. Allowing for asymmetric information in the analysis would lead to other interesting lines of research. Even with demand uncertainty there may be cases in which one firm knows more than the other. We could, for instance, consider a case in which one firm (with local knowledge) has better information about the market demand. These issues are left as topics for future research.

\section{Acknowledgements}

We are grateful to David Collie, Jonathan Eaton, Jan Haaland, Peter Neary, participants of the European Research in International Trade Workshop in Rotterdam (ERWIT-CEPR, June 1999), participants of the Econometric Society European Meeting in Santiago de Compostela (ESEM, September 1999), seminar participants at University College Cork, and an anonymous referee for helpful comments. G.D. acknowledges that the research work reported in this paper was financially assisted and supported through a Research Fellowship awarded by the ASEAN-EC Management Centre.

\section{Appendix A}

Table A. 1

Optimal rent-shifting subsidies for all possible investment timing combinations

$\begin{array}{ll}s^{\mathrm{cc} *} & \frac{1-(4 / 9) \eta[2-(4 / 3) \eta]}{2-(4 / 3) \eta} E x^{\mathrm{cc} *} \\ s^{\mathrm{dc} *} & \frac{3-2 \eta}{2\left[3-4 \eta+\eta^{2}\right]} E x^{\mathrm{dc} *} \\ s^{\mathrm{cd} *} & \frac{(3-2 \eta)^{2}-2 \eta(2-\eta)^{2}}{(3-2 \eta)^{2}(2-\eta)} E x^{\mathrm{cd} *} \\ s^{\mathrm{dd} *} & \frac{E \mathrm{xd}^{\mathrm{dd}}}{2-\eta} \\ \text { Note: } s^{\mathrm{dc}}>s^{\mathrm{dd}}>s^{\mathrm{cc}^{*}}>s^{\mathrm{cd} *} \text { for } A=A^{*} .\end{array}$

\section{References}

Arvan, L., 1991. Flexibility versus commitment in strategic trade under uncertainty. J. Int. Econ. 31, $341-355$.

Bagwell, K., Staiger, R., 1994. The sensitivity of strategic and corrective R\&D policy in oligopolistic industries. J. Int. Econ. 36, 133-150.

Boyer, M., Moreaux, M., 1987. Being a leader or a follower: reflections on the distribution of roles in duopoly. Int. J. Ind. Organization 5, 175-192. 
Brander, J., 1995. Strategic trade policy. In: Grossman, G., Rogoff, K. (Eds.). Handbook of International Economics, Vol. 3. North-Holland, Amsterdam. pp. 1395-1455.

Brander, J., Spencer, B., 1985. Export subsidies and international market share rivalry. J. Int. Econ. 18, 83-100.

Cooper, R., Riezman, R., 1989. Uncertainty and the choice of trade policy in oligopolistic industries. Rev. Econ. Studies 56, 129-140.

d'Aspremont, C., Jacquemin, A., 1988. Cooperative and non-cooperative R\&D in duopoly with spillovers. Am. Econ. Rev. 78, $1133-1137$.

de Meza, D., 1986. Export subsidies and high productivity, cause or effect?. Can. J. Econ. 19, 347-350.

Dewit, G., Leahy, D., 2001. Fighting Over Uncertain Demand: Investment Commitment Versus Flexibility. Economics Department Working Paper Series, N106/02/01. National University of Ireland, Maynooth.

Dixit, A., 1984. International trade policies for oligopolistic industries. Econ. J. 94 (Supplement), 1-16.

Dixit, A., Pindyck, R., 1994. Investment Under Uncertainty. Princeton University Press, NJ.

Dowrick, S., 1986. Von Stackelberg and Cournot duopoly: choosing roles. Rand J. Econ. 17, 251-260.

Eaton, J., Grossman, G., 1986. Optimal trade and industrial policy under oligopoly. Q. J. Econ. 101, $383-406$.

Gal-Or, E., 1985. First-mover and second-mover advantages. Int. Econ. Rev. 26, 649-653.

Goldberg, P., 1995. Strategic export promotion in the absence of government commitment. Int. Econ. Rev. 36, $407-426$.

Grossman, G., Maggi, G., 1998. Free trade vs. strategic trade: a peek into Pandora's box. In: Sato, R., Ramachandran, R.V., Mino, K. (Eds.), Global Integration and Competition. Kluwer, Dordrecht, pp. 9-32.

Hamilton, J., Slutsky, S., 1990. Endogenous timing in duopoly games: Stackelberg or Cournot equilibria. Games Econ. Behav. 2, 29-46.

Karp, L.S., Perloff, J.M., 1995. The failure of strategic industrial policy due to manipulation by firms. Int. Rev. Econ. Finance 4, 1-16.

Neary, J.P., 1994. Cost asymmetries in international subsidy games: should governments help winners or losers? J. Int. Econ. 37, 197-218.

Neary, J.P., Leahy, D., 2000. Strategic trade and industrial policy towards dynamic oligoplies. Econ. J. 110, 484-508.

Neary, J.P., O’Sullivan, P., 1999. Beat 'em or join 'em?: export subsidies versus international research joint ventures in oligopolistic markets. Scand. J. Econ. 101, 577-596.

Rodrik, D., 1992. Political economy and development policy. Eur. Econ. Rev. 36, 329-336.

Shapiro, C., 1989. Theories of oligopoly behaviour. In: Schmalensee, R., Willig, R. (Eds.), Handbook of Industrial Organization Vol. 1. North Holland, Amsterdam, pp. 329-414.

Spencer, B., Brander, J., 1983. International R\&D rivalry and industrial strategy. Rev. Econ. Studies 50, $707-722$.

Spencer, B., Brander, J., 1992. Pre-commitment and flexibility: applications to oligopoly theory. Eur. Econ. Rev. 36, $1601-1626$.

Stephens, M., 1999. The Changing Role of Export Credit Agencies. IMF, Washington, DC.

Tirole, J., 1988. The Theory of Industrial Organization. MIT Press, Cambridge, MA. 